$\mathrm{DOE} / \mathrm{PC} / 91008-0300$

Distribution Category UC-122

\title{
Native American Initiative Short Course \\ Management Plan
}

By

Herbert B. Carroll

April 1999

Work Performed Under Contract DE-AC22-94PC91008

(Original Report Number NIPER/BDM-0300)

\author{
Prepared for \\ U.S. Department of Energy \\ Assistant Secretary for Fossil Energy
}
National Petroleum Technology Office
P.O. Box 3628
Tulsa, OK 74101

Prepared by:

BDM-Oklahoma, Inc.

P.O. Box 2565

Bartlesville, OK 73005 


\section{DISCLAIMER}

This report was prepared as an account of work sponsored by an agency of the United States Government. Neither the United States Government nor any agency thereof, nor any of their employees, make any warranty, express or implied, or assumes any legal liability or responsibility for the accuracy, completeness, or usefulness of any information, apparatus, product, or process disclosed, or represents that its use would not infringe privately owned rights. Reference herein to any specific commercial product, process, or service by trade name, trademark, manufacturer, or otherwise does not necessarily constitute or imply its endorsement, recommendation, or favoring by the United States Government or any agency thereof. The views and opinions of authors expressed herein do not necessarily state or reflect those of the United States Government or any agency thereof. 


\section{DISCLAIMER}

Portions of this document may be illegible in electronic image products. Images are produced from the best available original document. 


\section{TABLE OF CONTENTS}

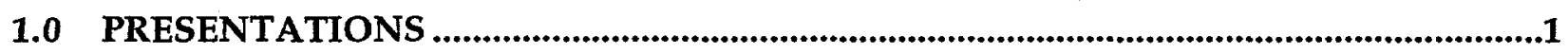

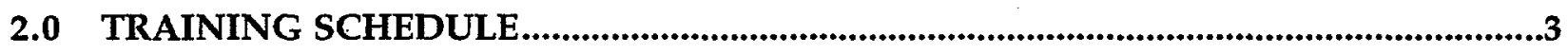

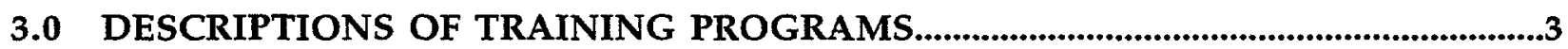

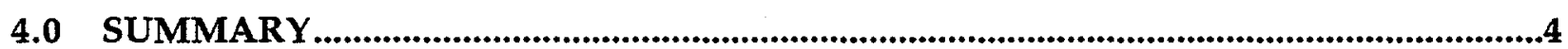

\section{TABLE OF CONTENTS}

1-1 Survey of Native American Tribal Training Needs-Tabulated Results .........................2

2-1 Proposed Schedule 1997 Short Courses for Native American Tribal Members ................3 


\section{NATIVE AMERICAN INITIATIVE SHORT COURSE MANAGEMENT PLAN}

\subsection{PRESENTATIONS}

A training program is outlined for members of Native American tribes having an interest in working in the oil and gas industry. Also, the program will assist tribes whose lands have oil and gas resources to become more familiar with the industry and technology necessary to develop their resources. The proposed program will contribute to meeting the goals of the U.S. Department of Energy's (DOE) Domestic Oil and Gas Initiative to help Native American tribes become more self-sufficient in developing and managing their resources through training in costeffective, improved technologies for hydrocarbon production that will meet environmental regulations.

The training program outlined is for adult tribal representatives who are responsible for managing tribal mineral holdings or setting policy, or who work in the oil and gas industry. The course content is in response to a survey that was developed by BDM-Oklahoma and sent in the spring of 1995 to 26 tribes or tribal agencies which were identified through previous contact with DOE. Tribes were asked to indicate course content needs, levels, preferred time of year, and location. Six tribes responded with specific recommendations and needs. These tribes include the Osage, Creek, Pueblo, Cherokee, St. Regis Mohawk, Northern Arapaho, and Ute Mountain Ute. The results of the survey are included in Table 1-1. 
Table 1-1 Survey of Native American Tribal Training Needs-Tabulated Results

\begin{tabular}{|c|c|c|c|c|c|}
\hline Tribe & $\begin{array}{l}\text { Special Course } \\
\text { Elements }\end{array}$ & Level & $\begin{array}{c}\text { Number } \\
\text { Participants }\end{array}$ & $\begin{array}{l}\text { Preferred } \\
\text { Time }\end{array}$ & Location \\
\hline $\begin{array}{l}\text { Cherokee Nation } \\
\text { Tahlequah, OK }\end{array}$ & Environmental Compliance & $\begin{array}{l}\text { elementary } \\
\text { intermediate } \\
\text { advanced }\end{array}$ & $10-15$ & winter & will travel \\
\hline $\begin{array}{l}\text { All Indian Pueblo Council } \\
\text { Albuquerque, NM }\end{array}$ & Environmental Compliance & $\begin{array}{l}\text { intermediate } \\
\text { advanced }\end{array}$ & & $\begin{array}{l}\text { summer } \\
\text { winter } \\
\text { spring }\end{array}$ & will travel \\
\hline & $\begin{array}{l}\text { Air Pollution Technologies } \\
\text { Air Quality Program } \\
\text { Management } \\
\text { Pollution Prevention } \\
40 \text { hr. OSHA Training } \\
\text { Emergency Response to } \\
\text { Hazardous Spills } \\
\text { Underground Storage Tanks } \\
\text { Groundwater Studies } \\
\text { Surface Water }\end{array}$ & $\begin{array}{l}\text { intermediate } \\
\text { advanced }\end{array}$ & $15-25$ & $\begin{array}{l}\text { summer } \\
\text { winter } \\
\text { spring }\end{array}$ & $\begin{array}{l}\text { on site or } \\
\text { travel }\end{array}$ \\
\hline $\begin{array}{l}\text { St. Regis Mohawk } \\
\text { Hogansburg, NY }\end{array}$ & $\begin{array}{l}\text { Environmental Compliance } \\
\text { Environmental Sampling } \\
\text { Spill Mitigation }\end{array}$ & $\begin{array}{l}\text { intermediate } \\
\text { advanced } \\
\text { advanced }\end{array}$ & & $\begin{array}{l}\text { fall } \\
\text { winter }\end{array}$ & on site \\
\hline $\begin{array}{l}\text { Ute Mountain Ute } \\
\text { Towaoc, CO } \\
\text {. }\end{array}$ & $\begin{array}{l}\text { Oil and Gas Environmental } \\
\text { Training-Oil Spills, Chemical } \\
\text { Spills, Water Disposal Wells } \\
\text { and Inspection Wells }\end{array}$ & $\begin{array}{l}\text { elementary } \\
\text { intermediate }\end{array}$ & & $\begin{array}{l}\text { surnmer } \\
\text { fall } \\
\text { spring }\end{array}$ & will travel \\
\hline $\begin{array}{l}\text { Muskogee (Creek) Nation } \\
\text { Muskogee, OK }\end{array}$ & Environmental Compliance & intermediate & & $\begin{array}{l}\text { fall } \\
\text { spring }\end{array}$ & will travel \\
\hline & $\begin{array}{l}\text { Basic Production Training and } \\
\text { Field Operation }\end{array}$ & elementary & & & will travel \\
\hline Northem Arapaho & $\begin{array}{l}\text { Environmental Compliance } \\
\text { Drilling and Completion }\end{array}$ & $\begin{array}{l}\text { intermediate } \\
\text { intermediate }\end{array}$ & $\begin{array}{l}2-4 \\
2-4\end{array}$ & $\begin{array}{l}\text { spring } \\
\text { spring }\end{array}$ & $\begin{array}{l}\text { will travel } \\
\text { will travel }\end{array}$ \\
\hline
\end{tabular}




\subsection{TRAINING SCHEDULE}

The training will be conducted at various locations by BDM-Oklahoma technical staff, which includes geologists, exploration and drilling specialists, oil and gas production specialists, environmental policy specialists, and contract specialists. The proposed training schedule offers three workshops per year and includes those courses identified in the survey by the tribes. The schedule initially proposed in April 1995 has been modified in order to offer training identified by the tribes in the most cost-effective manner. Participants will be able to take two courses, and travel costs will be minimized. A schedule is included in Table 2-1.

Table 2-1 Proposed Schedule 1997 Short Courses for Native American Tribal Members

\begin{tabular}{|c|c|}
\hline Tentative Dates & Courses \\
\hline \multirow[t]{6}{*}{ Feb. 1997} & Energy Training Unit \\
\hline & Introduction to Petroleum Geology \\
\hline & - Introduction to Petroleum Geology \\
\hline & - Oil \& Gas Production \\
\hline & - Environmental Management \\
\hline & $\begin{array}{l}\text { Doing Business with the U.S. Department } \\
\text { of Energy }\end{array}$ \\
\hline Spring 1997 & Energy Training Unit Repeated \\
\hline Fall 1997 & Energy Training Unit Repeated \\
\hline
\end{tabular}

Contracts have been initiated with several tribes to schedule a training workshop at various tribal locations. Currently, discussions are underway with the Hopi, Ute, Apache, and Osage tribes. Each of the tribal leaders are presenting the training program to their respective councils.

\subsection{DESCRIPTIONS OF TRAINING PROGRAMS}

The principal objective of the oil and gas production business is to make money. In today's economy, this has become very complex, encompassing many stages of technology application and investment strategies. However, the history of an oil well follows a predictable cycle. It starts with robust initial production (primary) and declines over time, going through improved recovery (water flooding, chemical recovery, or various other recovery techniques), until it reaches a stage called stripper well status. Eventually the accumulation of oil is depleted, and the well is then plugged and abandoned. This short course has been structured to provide an overview of oil production and management oriented to introduce the various technologies used in each phase. It is meant to review and explain oil production and economics for people with differing backgrounds and objectives from operating to investing. 
Introduction to Petroleum Geology: An overview of petroleum geology that includes how oil is formed, trapped, discovered, and produced. The presentation will focus on geologic tools and principles employed in the discovery and recovery of petroleum.

Oil and Gas Production: An introduction to production technology, including oil field terminology, leasing and owners' rights, and secondary production methods.

Environmental Management: An overview of federal environmental regulations that impact hydrocarbon exploration, drilling, and production operations. Examples will be discussed.

Doing Business with the U.S. Department of Energy: An introduction to the process of partnering with the Federal Government. The presentation will include information on how to identify, evaluate, and respond to contracting or subcontracting opportunities. Tips on writing a good proposal will be included.

\subsection{SUMMARY}

The training offered will be a continuation of the workshop started in October, 1996. Modifications to the course content will be integrated into the presentations to meet specific tribal needs. These special technology needs will be identified through discussions with tribal leaders and council members. 